7. Орлов Б.Н., Федосеева И.А., Иващенко М.Н. Влияние маточного молочка на агрегацию тромбоцитов. Материаль 4 Международной научнопрактической конференции «Пчеловодство - XXI век». Москва, 2003. C. 109-110.

8. Ульянич Н. В. Лечение продуктами пчеловодства. Київ, 1999. $283 \mathrm{c}$.

9. Хисматуллина Н. 3. Практическая апитерапия. Екатеринбург, 2013. $336 \mathrm{c}$.

10. Хомутов А.Е., Гиноян Р.В., Лушникова О.В., Пурсанов К.А. Апитерапия: монография. Нижний Новгород, 2014. 442 с.

11. Родионов А. Основы апитерапии. Краснодар, 2004. 284 с.

DOI https://doi.org/10.30525/978-9934-26-038-4-32

\title{
НЕОПЛАЗІЇ ПУПКОВОГО КАНАТИКА
}

\author{
Пилипчук I. C. \\ кандидат медичних наук, \\ асистент кафедри акушерства та гінекології \\ Львівський національний медичний університет \\ імені Данила Галищького \\ Флуд В. В. \\ кандидат медичних наук, \\ асистент кафедри акушерства та гінекології \\ Львівський начіональний медичний університет \\ імені Данила Галищького \\ Пилипчук C. I. \\ студентка II курсу медичного факультету \\ Львівський національний медичний університет \\ імені Данила Галищького \\ м. Львів, Україна
}

Патологія пупкового канатика різноманітна. Це аномалії розмірів та товщини пуповини, просторового розміщення судин, розміщення фрагментів пуповини один відносно одного та плода, патологія Вартонових драглів, відсутність пуповини, судинні аномалії, неоплазії [1, с. 34-65]. Частота, з якою зустрічається патологія пуповини різна, від «звичного» для акушерів-гінекологів обвиття, до рідкісних форм, - 
пухлин. Наслідки для завершення вагітності та здоров'я плода: від відсутності будь якого впливу (обвиття пуповиною) до антенатальної загибелі плода (перекрут, тромбоз, стеноз, компресія судин, інтраамніальна кровотеча). За даними T. Vougioklakis et al., у 32 випадках гемангіоми пуповини спостерігався у $10(31,3 \%)$ позитивний перинатальний результат, у 22 випадках $(68,7 \%)$ - перинатальна смерть плода [3, c.75-79]. E. Danirl-Spiegel et al., наводять дані про випадки перинатальної смертності $(37,5 \%)$ та перинатальна захворюваність $(33,3 \%)$ у плодів, у яких діагностовано гемангіому пуповини [4, с. 300-303].

Неоплазії пуповини спостерігаються вкрай рідко. Достовірних даних про їх частоту у сучасній літературі, поки що не наводиться. Рандомізовані дослідження по даній проблемі, наразі не проводились. За гістологічною будовою розрізняють:

- ангіому (ангіоміксома, кавернозна гемангіома, гемангіофіброміксома, міксангіома, телеангіектатична міксосаркома);

- тератому.

Гемангіома пуповини - це пухлина, яка розвивається з ендотеліальних клітин судин пуповини, зустрічається в деякій мірі частіше ніж ангіома [5, с.1-2]. Пухлина може досягати розміру діаметром 15 см і більше. Вона складається із ангіоматозних вузликів, які оточені набряклим міксоматозно видозміненим Вартоновим студнем. Найчастіше пухлина локалізується ближче до плацентарного кінця пуповини. Джерелом розвитку пухлини служать основні судини пуповини. В патологічний процес можуть втягуватися декілька судин. Типова мікроскопічна картина пухлини представлена множинними судинними каналами, які вистелені ендотелієм, з набряком та міксоїдною дегенерацією строми пуповини [9, с. 360-363]. Гемангіома пуповини має вигляд гіперехогенного утвору [2, с. 303-305]. Диференційна діагностика цього виду аномалії проводиться із тератомою та гематомою пуповини. Диференційний діагноз між гемангіомою і гематомою пуповини полягає у виявленні ендотеліального вистелення знову утворених капілярів і позитивному забарвленні імунопероксидазою антигена до VIII фактору. Розвиток гемангіоми пуповини супроводжується підвищенням рівня альфафетопротеїну [8, с.140-142]. Часто дана патологія поєднується із неімунною водянкою, а це в свою чергу призводить до тяжкого стану плода, високого рівня захворюваності та смертності. У літературі описано випадок поєднання гемангіоми пуповини з вираженою дифузною гемангіомою шкіри (Seifer D.B. et al., 1985). Поєднані судинні неопластичні процеси із плацентарною гемангіомою зустрічаються у 10\%. Діагностика аномалій пуповини слугує показанням до динамічного ехографічного та допплерівського контролю стану плода, діагностики плацентарної дисфункції, синдрому затримки розвитку плода, змін розмірів 
пухлини, здавлення судин пуповини великою пухлиною, виявлення ознак неімунної водянки плода [6, с. 328-331]. При пухлинах великих розмірів рекомендовано проводити родорозрішення відразу після підтвердження зрілості легень у плода.

Тератома пуповини - у літературі описано близько 15 випадків тератоми пуповини. Частото відбувається постнатальна верифікація діагнозу, після патолого-гістологічного дослідження посліду.

Під час емріогенезу клітини зародка від дорсальної стінки жовточного мішка мігрують до генітального гребеня по брижі примітивної кишки. Оскільки пуповина формується в ранні терміни вагітності із вип'ячуваня примітивної кишки, клітини зародка можуть потрапляти в пуповину на цьому етапі розвитку. Можливо, що деякі тератоми в дійсності представляють собою акардіального близнюка і навпаки [7, с. 55-58].

Розміри пухлини можуть перевищувати 9 см. в діаметрі. Гістологічно неоплазія містить елементи, які походять 3 трьох ембріональних шарів, має здатність до кальцифікації. Тератома може розвиватися на будь якому відрізку пуповини, вимагає приналежного спостереження за станом плода та кровоплином в системі мати-плацента-плід, ознаками неімунної водянки плода.

Патологія пуповини спричинює певні перинатальні наслідки для плода, від не порушеного стану аж до його загибелі, тому вимагає приналежного ставлення до діагностики стану системи мати-плацента-плід та вчасного надавання акушерської допомоги.

\section{Література:}

1. Гагаев Ч.Г. Патология пуповины / под ред. В.Е. Радзинского. Москва, 2011.95 с.

2. Галкина О.Л., Шмакова Н.В., Старченко Л.П. Случай преанатальной диагностики гемангиомы пуповины. Пренатальная диагностика. 2007. № 6 (4). С. 303-305.

3. Гольцфарб С.М., Гаврикова О.А., Блинов А.Ю., Шеломенцева В.В. Ангиомиксома пуповины: случай пренатальной диагностики во втором триместре беременности. Пренатальная диагностика. 2010. № 9 (1). С. 75-79.

4. Daniel-Spiegel E., Weiner E., Gimburg G. The association of umbilical cord hemangioma with fetal vascular birthmarks. Prenatal Diagnosis. 2005. № 25 (4). C. 300-303.

5. Papadopoulos V.G., Kourea H.P., Adonakis G.L., Decavalas G.O. A case of umbilical cord hemangioma: doppler studies and review of the literature. Eur J Obstet Gynecol Reprod Biol. 2009 . № 144 (1). C. 1-2. 
6. Kamitomo M., Sueyoshi K., Matsukita S. et al. Hemangioma of the umbilical cord: stenotic change of the umbilical vessels. Fetal Diagn Ther. 1999. № 14 (6). C. 328-331.

7. Tennstedt C., Chaoui R., Bollman R., Dietel M. Angiomyxoma of the umbilical cord in one twin with cystic degeneration of Wharton's jelly. A case report. Pathol Res Pract. 1998. № 194(1). C. 55-58.

8. Bruhwiler H., Rabner M., Luscher K.P. Prenatal diagnosis of umbilical cord hemangioma in increased alpha-fetoprotein. Ultraschall Med. 1994. № 15 (6). C. 140-142.

9. Cheng H.P., Hsu C.Y., Cheng C.P., Su T.H. Angiomyxoma of the umbilical cord. Taiwan J Obstet Gynecol. 2006. № 45(4). C. 360-362.

DOI https://doi.org/10.30525/978-9934-26-038-4-33

\title{
ГЕНДЕРНІ ТА ВІКОВІ ОСОБЛИВОСТІ ПОШИРЕНОСТІ ПОСДНАННЯ ЦУКРОВОГО ДІАБЕТУ ТА ПЕПТИЧНОЇ ВИРАЗКИ У ЛЬВІВСЬКІЙ ОБЛАСТІ
}

\author{
Пода Н. В. \\ підполковник медичної служби, \\ начальник гастроентерологічного відділення \\ Військово-медичний клінічний центр Західного регіону \\ м. Львів, Украӥна \\ Гук-Лешневська 3. О. \\ кандидат медичних наук, \\ доиент кафедри внутрішньої медицини № 2 \\ Львівський начіональний медичний університет \\ імені Данила Галицького \\ м. Львів, Украӥна
}

Цукровий діабет (ЦД) вважається хворобою, яка розглядається як епідемія у всьому світі. Всесвітня організація охорони здоров'я повідомляє, що в даний час на планеті налічується більше 130 млн. людей хворих на ЦД, лише в США, зокрема, близько п'яти мільйонів діабетиків $[1,2]$. Україна, де зараз зареєстровано понад 1 млн. хворих, входить до першої десятки країн світу за поширеністю ЦД [3, 4, 5].

Не зважаючи на успіхи в лікуванні пептичної виразки (ПВ) шлунка та дванадцятипалої кишки, її поширеність також є високою в світі. ПВ страждають від 10 до $20 \%$ населення світу [6]. В Україні показник 